\title{
Thalidomide induces imbalances in T-lymphocyte sub-populations in the circulating blood of healthy males
}

\author{
S M GAD,* E J SHANNON, W A KROTOSKI \\ \& R C HASTINGS
}

Pharmacology Research Department, National Hansen's Disease Center, Carville, Louisiana 70721, USA; * Alexandria Le prosarium, Alexandria, Egypt

Accepted for publication 9 August 1984

\begin{abstract}
Summary Lepromatous leprosy patients experiencing erythema nodosum leprosum (ENL) have been reported to have an increase in the ratio of circulating $\mathrm{T}$-helper to $\mathrm{T}$-suppressor cells $(\mathrm{H}: \mathrm{S}$ ratio). Thalidomide is an effective drug in the management of ENL. To determine if thalidomide affected cells of the immunoregulatory system, B cells, T cells, T-suppressor cells, T-helper and natural killer cells in the blood of the healthy males were enumerated. Thalidomide induced a decrease in the T-helper to T-suppressor cell ratio. The decrease was due to a significant reduction in the percentage and absolute number of $\mathrm{T}$-helper cells and an apparent increase in the percentage and absolute number of T-suppressor cells. B cells and natural killer cells were not affected.

Thalidomide's ability to decrease the $\mathrm{H}: \mathrm{S}$ ratio in healthy individuals suggests that it may act in ENL by reducing an elevation of that ratio.
\end{abstract}

Thalidomide is well documented as being an effective treatment for erythema nodosum leprosum (ENL) occurring in lepromatous leprosy. ${ }^{1.2}$ The full pathogenesis of this syndrome is unknown and it has been proposed that ENL is precipitated by, or at least is associated with, an acute imbalance in immunoregulatory T-lymphocyte subsets. ${ }^{3}$

To determine if thalidomide affected the balance of immunoregulatory $\mathrm{T}$ cells, we enumerated the percentage and absolute numbers of lymphocyte subsets in the blood by direct fluorescence microscopy. T cells, T-suppressor cells, $\mathrm{T}$-helper and natural killer cells were determined using the fluorescein-conjugated mouse monoclonal antibodies Leu-1, Leu-2a, Leu-3a and Leu-7, respectively. B cells were enumerated using a fluorescein conjugated $\mathrm{F}\left(\mathrm{ab}^{\prime}\right)_{2}$ fragment of a rabbit anti-human $\operatorname{IgG} F\left(\mathrm{ab}^{\prime}\right)_{2}$. 


\section{Materials and methods}

\section{HUMAN SUBJECTS}

Thalidomide (Grunenthal GMBH 5190 Stolberg/Rhld, Federal Republic of Germany), was administered to 6 healthy males after obtaining their informed consent. The volunteers were employees of the National Hansen's Disease Center in Carville, Louisiana; their ages ranged from 26 to 56 years with a median age of 36 years. Thalidomide was taken orally in doses of $100 \mathrm{mg}$ every $12 \mathrm{~h}$ for 4 days. The subjects were taking no other medications immediately prior to, or during the study.

\section{CELL SEPARATIONS}

Leukocytes were enumerated using a Coulter counter (Coulter Electronics, Inc, Hialeah, Florida), and differential counts were performed on peripheral blood smears stained with Wright's stain. Heparinized venous blood was drawn and diluted $1: 2$ with normal saline, and $20 \mathrm{ml}$ of the dilution was layered over $6 \mathrm{ml}$ of Ficoll-Hypaque (Lymphoprep ${ }^{\circledR}$, Gallard-Schlesinger Chemical MFG, Co, Carle Place, New York). After centrifugation at $400 \times \mathrm{g}$ for $45 \mathrm{~min}$ at $20^{\circ} \mathrm{C}$, the mononuclear cells were collected.

\section{DETERMINATION OF LYMPHOCYTE CELL SURFACE MARKERS}

B-lymphocytes were identified by direct fluorescence microscopy as previously described ${ }^{4}$ using fluorescein conjugated $F\left(a b^{\prime}\right)_{2}$ fragment of rabbit anti-human IgG F $\left(\mathrm{ab}^{\prime}\right)_{2}$ (Cappel Laboratories, Cochranville, PA). T-lymphocyte phenotype markers were determined as described for B-lymphocytes, using monoclonal antibodies Leu-1 ( $\mathrm{T}$ cells), Leu-2a (cytotoxic/suppressor), Leu-3a (helper/inducer), and Leu-7 (natural killer cells) (Becton Dickinson, Sunnyvale, CA).

Absolute levels of lymphocytes bearing a given phenotype or surface immunoglobulin were calculated from the product of (a) leukocyte counts, (b) the percentage of lymphocytes on differential counts, and (c) the proportion of mononuclear cells, corrected for monocytes by peroxidase staining, that fluoresced with a particular fluorescein conjugated antibody.

\section{Results}

Table 1 summarizes the effects of ingestion of thalidomide by healthy male volunteers on T cells, $T$ cell subsets, and B cells. Using the paired t-test analysis to compare baseline values determined prior to ingestion of $200 \mathrm{mg}$ of thalidomide 
Table 1. T cells, T cell subsets and B cells enumerated by direct fluorescence microscopy

\begin{tabular}{cccccccccccc}
\hline \multicolumn{1}{c}{ Mean percent \pm standard } \\
deviation (N) fluorescent cells ${ }^{\mathrm{a}}$ \\
among peroxidase negative \\
mononuclear cells \\
(lymphocytes)
\end{tabular}

a Leu-1 directed against all T-lymphocytes.

Leu-3a directed against helper/inducer lymphocytes.

Leu-2a directed against cytotoxic/suppressor lymphocytes.

Leu-7 directed against natural killer cells.

$\mathrm{Ig}^{+}$directed against surface immunoglobulin and identifying B-lymphocytes.

b $0=$ Baseline prior to ingestion of $100 \mathrm{mg}$ of thalidomide.

$4=4$ th day after ingestion of $200 \mathrm{mg}$ of thalidomide/day.

$18=18$ th day after baseline study and 2 weeks after thalidomide stopped.

${ }^{*}-P<0.05$ one tail paired $\mathrm{t}$-test, compared with day 0 .

$* *-P<0.01$

$* * *-P<0.005$

$* * * *-P<0.001$

per day, the drug induced a significant decrease $(P<0.001)$ in the circulating T-helper (Leu-2a) to T-suppressor (Leu-3a) cell ratio after 4 days (Figure 1). The post-treatment helper:suppressor $(\mathrm{H}: \mathrm{S})$ ratio returned to baseline levels 2 weeks after thalidomide was stopped. The decreased helper: suppressor ratio $(\mathrm{H}: \mathrm{S})$ was due to a highly significant decrease $(P<0.01)$ in the percentage and absolute numbers of circulating T-helper cells and an apparent increase $(P<0.05)$ in the percentage and absolute numbers of $\mathrm{T}$-suppressor cells (Figure 1). The percentages and absolute numbers of natural killer and B cells were not altered. 

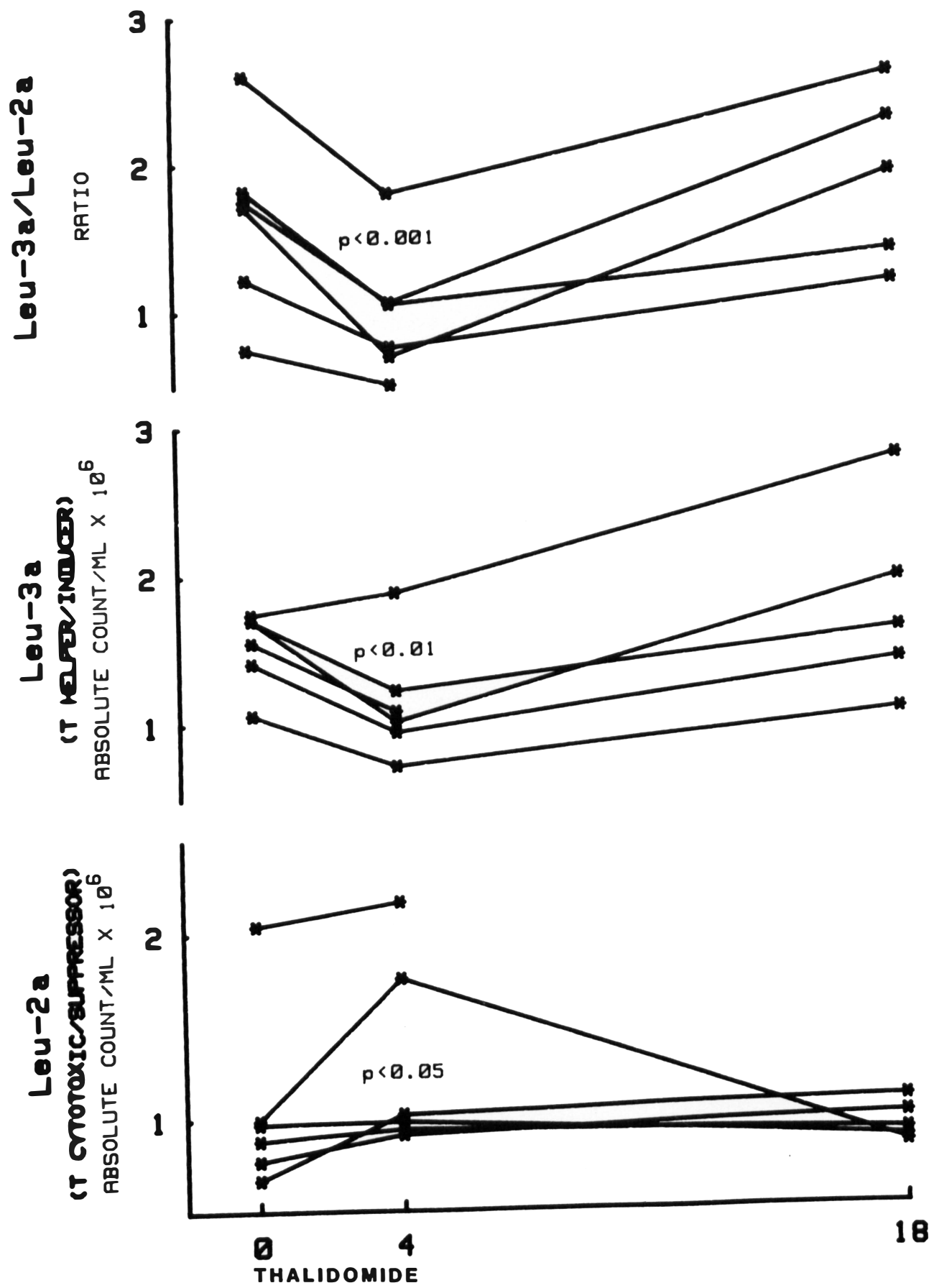

DAYS

Figure 1. The circulating T-helper (Leu-2a) to T-suppressor (Leu-3a) cell ratio after 4 days. 


\section{Discussion}

Lepromatous leprosy patients experiencing ENL have a significant increase in their $\mathrm{H}: \mathrm{S}$ ratio. ${ }^{5-7}$ Thalidomide's ability to decrease the $\mathrm{H}: \mathrm{S}$ ratio significantly in healthy individuals suggests that it may act in ENL by reducing an elevated $\mathrm{H}: \mathrm{S}$ ratio. This site of action would explain many of the immunosuppressive activities of thalidomide in a variety of both humoral and cell mediated immune systems.

\section{Acknowledgments}

We would like to thank Mrs R Painter and Mr M Morales of the Pharmacology Research Department, National Hansen's Disease Center, Carville, Louisiana, for their help in preparing the manuscript. Dr Gad received financial support from the Peace Fellowship Program for Egypt, American-Mideast Educational and Training Service, Inc (AMIDEAST).

\section{References}

1 Sheskin J. Thalidomide in the treatment of lepra reactions. Clin Pharmacol Ther, 1965; 6: 303-6.

2 Hastings RC, Trautman JR, Enna CD, Jacobson RR. Thalidomide in the treatment of erythema nodosum leprosum, with a note on selected laboratory abnormalities in erythema nodosum leprosum. Clin Pharmacol Ther 1970; 11: 481-7.

${ }^{3}$ Mshana RN. Hypothesis: erythema nodosum leprosum is precipitated by an imbalance of T-lymphocytes. Lepr Rev, 1982; 53: 1-7.

${ }^{4}$ Shannon EJ, Hastings RC. Methods for identification of human B-lymphocytes. $J$ of Immunol Methods, 1977; 18: 321-35.

5 Wallach D, Cottenot F, Bach MA. Imbalances in T cell subpopulations in lepromatous leprosy. Int J Lepr, 1982; 50: 282-90.

${ }^{6}$ Bach MA, Chatenoud L, Wallach D, Phan Dinh Tuy F, Cottenot F. Studies on T cell subsets and functions in leprosy. Clin Exp Immunol, 1981; 45: 449-56.

${ }^{7}$ Mshana RN, Haregewoin A, Harboe M, Belehu A. Thymus dependent lymphocytes in leprosy 1. T-lymphocyte subpopulations defined by monoclonal antibodies. Int J Lepr, 1982; 50: 291-6. 